\title{
МАТЕРІАЛИ ОСОБОВИХ ФОНДІВ АРХІВІВ І БІБЛІОТЕК УКРАЇНИ ЯК ДЖЕРЕЛО ДОСЛІДЖЕННЯ ПЕДАГОГІЧННИХ ПЕРСОНАЛІЙ
}

Джерела особового походження відіграють особливу роль у проведенні історико-педагогічних досліджень. Хоча теорія і практика їхньої диференціації, аналізу, використання знайшли достатнє наукове обгрунтування, багато аспектів цієї проблеми залишаються предметом наукового дискурсу. Їх виокремлюють за ознакою походження і визначають як документи, що виникли в процесі життя і діяльності окремої особи, сім'ї, родини. Їм часто відмовляють у статусі «офіційних», хоча вони могли створюватися як 3 приватною, так і з офіційною метою.

Джерела особового походження умовно розділяємо на дві основні загальні групи. Перша - це видані офіційними органами документи (свідоцтва про народження, шлюб, освіту, майновий стан, нагороди; облікові картки, службові характеристики тощо). Друга - це мемуаристика - спогади, щоденники, подорожні нотатки, епістолярій, інша література, що розділяється за жанровими ознаками. Їхня специфічна риса як науково-пізнавального ресурсу полягає в тому, що вони, з одного боку, відображають розмаїття суспільних процесів, явищ, відносин через призму суб'єктивної позиції автора, з іншого, рельєфно віддзеркалюють його світогляд і персональне бачення подій. Закладена в мемуаристиці інформація часто відсутня в інших джерелах, тож вони дозволяють історикові педагогіки глибше, колоритніше, 3 позицій альтернативності реконструювати життєвий шлях та різні напрями діяльності досліджуваної персоналії.

Науково-теоретичні засади використання джерел особового походження в дослідницькій діяльності продуктивно опрацьовуються з позицій літературознавства і документалістики (О. Галич, Е. Местергазі, Т. Пустовіт, М. Федунь), історичного джерелознавства (С. Макарчук, М. Казьмирчук, О. Косенко, С. Павленко, О. Ясь), правознавства (С. Кодан), біографістики (М. Гончаренко, Н. Любовець, Т. Черкашина), а також історикопедагогічної науки (М. Анісов, Г. Белан, Л. Голубнича, Н. Дічек, Т. Завгородня, Д. Раскін, О. Петренко, Л. Смолінчук, О. Сухомлинська та ін.), психології (Н. Логінова), інших галузей знань. Хоча цей доробок має чимало дискусійних моментів і різночитань, він може бути оптимально адаптований до потреб дослідження педагогічних персоналій.

Аналіз дисертаційних і монографічних досліджень про педагогічні персоналії показав, що їхні автори (за умов наявності) активно використовують фонди особового походження архівних i бібліотечних установ. Однак їхній узагальнювальний аналіз з позицій історико-педагогічної науки відсутній. Важливе підгрунтя для заповнення цієї прогалини дають довідникові й аналітичні публікації [1-6 та ін.] і безпосередне ознайомлення з їхнім наповненням.

Мета статті полягає в аналізі наповнення фондів особового походження архівів і бібліотек України джерельними матеріалами про педагогічні персоналії та з'ясуванні їхнього видового розмаїття і можливостей використання в дослідницькій роботі.

Наприкінці 80-х pp. XX ст. особові фонди існували фактично в усіх центральних і обласних державних архівах України, їхня загальна кількість становила 1227, а обсяг 92,3 тис. умовних одиниць зберігання - справ [2, с. 201-202]. Вони формувалися стихійно за рахунок передачі документів із приватних архівів та 3 офіційних громадських і державних організацій. Попри розмаїття документального наповнення, ці фонди передусім є джерелом вивчення різних напрямів людської діяльності, де на перший план виступає індивідуальна творчість - письменників, істориків, митців, педагогів [5].

Масштабність цього явища засвідчує, до прикладу, факт нагромадження у Центральному державному архіві-музеї літератури і мистецтва України понад тисячі особових архівних фондів, а в Інституті рукопису Національної бібліотеки України імені В. І. Вернадського (IP НБУВ) 264 [4]. В Інституті архівознавства НБУВ, що є головним архівним підрозділом в системі НАН України з питань формування, зберігання, обліку і використання документів архівного фонду України, зберігається близько 280 фондів академіків і членів-кореспондентів, серед яких є чима- 
ло відомих педагогів. У ЦДІАК України зосереджені родові фонди землевласників та відомих громадських діячів, учених, просвітян XVIIIXX ст. [2, с. 202-203].

В обласних державних архівах чисельність родинних і особових фондів коливається, до прикладу, від шести у Херсонському [5] до 34 (6388 справ за 1693-2010 рр.) у Полтавському [1] тощо.

Аналіз показав, що питома вага особових фондів у центральних і обласних архівних і бібліотечних установах, які належать педагогам, є відносно невисокою. При цьому вони репрезентують величезний масив матеріалів, що відображають життя і творчість осіб, які відзначилися в царині освіти і педагогіки та в різних вимірах відображають їхній розвиток. Це, приміром, стосується багатьох матеріалів із понад півмільйона рукописних документів, зосереджених в особових фондах ІР НБУВ. 3 одного боку, ідеться про відомих істориків (Д. Багалій, М. Біляшівський, М. Брайчевський, Д. Дорошенко, В. Іконніков, I. Луцький та ін.), математиків (Д. Граве, М. Остроградський та ін.), медиків, економістів, юристів, представників інших галузей знань, які зробили вагомий внесок у розробку навчальнометодичного забезпечення цих галузей знань та відзначилися в ділянці громадського просвітництва i розбудови національного шкільництва тощо. Тут зосереджені особові фонди відомих літераторів і громадських діячів (Б. Грінченко, М. Драгоманов, М. Костомаров, П. Куліш, О. Русов та ін.), що активно досліджуються як педагогічні персоналіі. Поряд із біографічними документами (автобіографії, облікові картки тощо) у них зберігаються рукописи маловідомих різножанрових творів, які стосуються різних питань теорії і практики освіти, навчання і виховання, а також конспекти лекцій, інші методичні матеріали [4].

3 іншого боку, в IP НБУВ $є$ особові фонди маловідомих педагогів, зокрема в особі викладачів (Д. Богдашевський, С. Голубєв, Т. Лященко, М. Петров та ін.), заборонених радянською владою, Київського університету св. Володимира, Київської духовної академії, Київської духовної семінарії, багатьох гімназій [4]. Цей масив документів має вивчатися істориками педагогіки.

Значна кількість особових фондів педагогічних персоналій зосереджена в Центральному державному історичному архіві м. Львова (ЦДІАЛ) України, тож із їхньої загальної кількості - близько 90 - для аналізу було відібрано 19. Їхніх фондоутворювачів умовно розділяємо на дві основні групи. Першу становлять відомі педагоги, просвітяни, учені, громадські й державні діячі, які зробили вагомий внесок у вивчення історії освіти, розвиток теорії і практики навчання і ви- ховання, а також українського шкільництва і просвітництва в другій половині XIX - 30-х рр. XX ст. (І. Боберський, А. Вахнянин, В. Левицький, I. Гриневецький, Я. Гординський, І. Крип' якевич, А. Крушельницький, О. Маковей. Ю. Романчук, О. Тисовський. П. Франко, Г. Хоткевич, В. Шухевич). До другої групи віднесено знаних громадських діячів, учених, у фондах яких зберігаються цінні для історико-педагогічної біографістики джерельні матеріали (О. Басараб, О. Охримович, К. Студинський). Предметного розгляду потребує їхнє інформативно-змістове наповнення.

Документи цих особових фондів охоплюють період другої половини XIX - першої половини XX ст. та стосуються освітньо-педагогічних процесів різних регіонів України. Їхній обсяг коливається від 12 до 522 справ. У структурному відношенні їх можна розділити на кілька частин: а) офіційні біографічні матеріали (свідоцтва про шлюб, освіту, облікові картки тощо); б) мемуарні матеріали (автобіографії, спогади, щоденники, подорожні нотатки та ін.); в) матеріали про громадську культурно-освітню і службову діяльність; г) матеріали, що відображають творчу i наукову працю (тексти публікацій або їхні фрагменти, чернетки тощо); г) навчально-методичне забезпечення; д) листування з офіційними інституціями і приватними особами; є) матеріали про фондоутворювача (некрологи, рецензії, майновогосподарські документи тощо); е) родинні архіви, фотографіï; є) матеріали про інших осіб тощо.

До прикладу, доволі репрезентативним 3 позицій історико-педагогічної біографістики виглядає фонд 410 ЦДІАЛ України О. Тисовського (1886-1968), професора біології, педагога, засновника и головного ідеолога української скаутської організації «Пласт». Зміст його 157 справ становлять біографічні і особисті документи (автобіографія, спогади, бібліографія праць 1939 р. тощо); матеріали про творчу i педагогічну діяльність (наукові й методичні праці, підручники, конспекти лекцій, реферати з педагогіки, біології, зоологіï, філософіiі, психології) про пластовий рух; документи про освітню політику УНР і ЗУНР; листування з культурно-освітніми установами та відомими педагогами і громадськими діячами.

Доволі інформативними також є колекції особових документів відомих педагогів і громадсько-освітніх діячів: І. Боберського (1873-1947) визначного теоретика фізичного виховання й організатора українського спорту (ф. 366, 30 справ); письменника О. Маковея (1867-1925), що, зокрема, містить матеріали про його роботу в учительських семінаріях у Заліщиках, Львові, Чернівцях та листування з УПТ, іншими освітніми товариствами (ф. 386; 67 справ); В. Шухевича 
(1850-1915), що був редактором часописів «Дзвінок» $\mathrm{i}$ «Учитель» (ф. 735; 18 справ); письменника, громадського діяча, одного $з$ фундаторів українського скаутингу П. Франка (1902-1941) (ф. 640; 12 справ) та ін.

Особові фонди (поряд із персональнобіографічними даними) містять унікальні документи про державницьку i національнополітичну діяльність знаних педагогів і громадських діячів щодо захисту й розвитку національної освіти і шкільництва. 3 таких позицій становить інтерес фонд 361 ЦДІАЛ України А. Крушельницького (1878-1937), письменника, педагога, громадсько-політичного діяча, в якому, зокрема, зберігаються матеріали про його діяльність як міністра освіти УНР (1919-1920), голови педагогічної місії у справах видавництва підручників УНР у Відні (1919-1923), організатора українського університету у Львові, а також про участь у видавничих товариствах, листування 3 Д. Дорошенком, О. Кисілевською, О. Кобилянською, О. Маковеєм, І. Огієнком, В. Стефаником тощо.

У ф. 382 «Романчук Юліан (1842-1932), політичний і громадський діяч, педагог, письменник, журналіст» зосереджені документи про його діяльність як очільника «Просвіти» та публічні виступи 3 питань українського шкільництва як голови об'єднання українського депутатського клубу в австрійському парламенті (1890-1926).

3 таких же позицій відзначаємо особовий фонд композитора, письменника, педагога, громадська діяча А. Вахнянина (1841-1908) (ЦДІАЛ України, ф. 818, 39 справ), де поряд зі статтями 3 історії освіти, матеріалами про діяльність «Пласту» тощо вміщені тексти виступів як депутата Галицького сейму 3 питань освітньої і педагогічної діяльності, а також офіційне і приватне листування, зокрема з В. Барвінським, Ю. Гладиловичем, В. Пачовським, К. Трильовським, іншими педагогами і просвітянами.

Серед особових фондів вищеозначеної другої групи є цінні документи з історії української освіти і шкільництва. Зокрема, у найбільш репрезентативній збірці документів відомого історика мови і літератури, голови НТШ, академіка ВУАН К. Студинського (ф. 362, 522 справи), окрім численних біографічних документів і спогадів, епістолярію, зберігаються матеріали про його громадську і службову діяльність як голови комісії із заснування українського університету у Львові (1922-1930), листування із Крайовою шкільною радою, також наукові праці про О. Духновича, М. Смотрицького, інших педагогів і діячів тощо. 3 таких же позицій становить інтерес особовий фонд визначного історика I. Крип'якевича (1886-1967) (ф. 357; 62 справи).

Біографічні матеріали особових фондів другої групи проливають світло на різні аспекти освітньо-виховних процесів західноукраїнських земель кінця XIX - середини XX ст. До прикладу, у ф. 372 письменника, етнографа, громадського діяча В. Охримовича (1970-1931) зберігається унікальний автобіографічний нарис «Моє життя i мої знайомі», що розкриває панораму культурного середовища Львова і Відня кінця XIX 30-х pp. XX ст. Його доповнює листування з товариствами «Просвіта», «Академічна громада», «Січ», багатьма відомими діячами [ф. 372].

Попри різну наповненість біографічними й іншими документальними матеріалами спільною рисою особових фондів ЦДІАЛ України є широкий епістолярій. Навіть формальний аналіз прізвищ, зафіксованих у назвах справ, дозволяе говорити про існування системних особистих стосунків між 20-30 відомими педагогами, вченими, культурно-освітніми діячами різних регіонів України кінця XIX - 30-х pp. XX ст. Зокрема: В. Барвінським, О. Барвінським, В. Бачинським, I. Боберським, А. Вахнянином, С. Гайдучком, Ю. Гладиловичем, Я. Гординським, І. Гриневецьким, М. Грушевським, Д. Дорошенком, М. Драгомановим, В. Кисілевським, О. Кисілевською, О. Кобилянською, I. Крип'якевичем, А. Крушельницьким, В. Левицьким (Василь Лукач), Б. Лепким, О. Маковеєм,

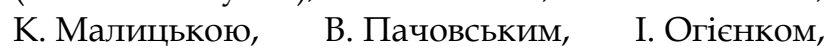
В. Охримовичем, С. Русовою, Й. Сліпим, К. Студинським, К. Трильовським, Ю. Федьковичем, I. Франком, Г. Хоткевичем, В. Щуратом та багатьма іншими.

Ще більш неосяжний і менш опрацьований 3 позицій історико-педагогічної біографістики масив джерельних матеріалів зосереджений у відділі рукописів Львівської національної бібліотеки ім. В. Стефаника (ЛНБ). Серед упорядкованих у ньому наприкінці 80-х рp. XX ст. близько 175 особових фондів [3] (а їхнє формування продовжується), близько 2/3, згідно 3 нашими підрахунками, належить особам, які заслуговують на дослідження як педагогічні персоналії.

3 них для предметного аналізу було відібрано 25 особових фондів як досить відомих, так i майже не знаних українських і польських діячів педагогів, учених, просвітників, викладачів, професорів університетів і гімназій, шкільних урядовців, учителів, чия діяльність припадає на період від 30-х рр. XIX до 60-ті pp. XX ст. Серед них відзначаємо Т. Гушалевича (1846-1915) - філолога, педагога, учителя І. Франка у Дрогобицькій гімназії (1868-1892), редактора газети «Учитель» (1890-1892), укладача шкільних підручників, відомих українських педагогів О. Духновича (1803-1865) і Ф. Науменка (1901-1991), Н. Кобринську (1855-1920) - знану письменницю, просвітницю й засновницю українського жіночого руху та ін. 
Обсяги цих фондів коливаються від 150 до 10 тис. аркушів, тож і їхня змістова наповненість є різною. Загалом серед них переважають біографічні матеріали (автобіографії, спогади, особово-облікові документи тощо) та матеріали навчально-методичного забезпечення, що відображають не лише викладацьку, а й навчальну діяльність персоналій у гімназіях, семінаріях, університетах тощо.

Виходячи $з$ доробку вчених (М. Казьмирчук, С. Кодан, О. Косенко, С. Павленко, О. Ясь та ін.), визначаємо три основні науково-методологічні підходи до вивчення і використання джерел особового походження 3 позицій історикопедагогічної біографістики. Згідно з першим інформаційним - вони розглядаються як носії інформації, що відображають реальну дійсність минулого та як спосіб ії кодування, в якому об'єкт - це сама реальність, суб'єкт (персоналія) творець джерела, інформація - це результат відображення об'єкта суб'єктом. Необхідно враховувати прагматичний аспект цього процесу, адже творець такого джерела завжди має певну ціль, що відповідним чином позначалося на якості інформації.

Другий підхід - комунікативний - відображає часовий зв'язок творця джерела із суспільством, який відбувається у двох вимірах: із сучасним соціокультурним середовищем та 3 попередніми і наступними генераціями. Це дозволяє розглядати персоналію на перетині і в контексті різних епох, визначаючи іï роль, місце, значення в історії розвитку педагогічної думки та актуальність їі ідей для сьогодення. Третій біографічний - підхід безпосередньо пов'язаний 3 джерелом особового походження, тож передбачає вивчення особливостей життєвого шляху i продуктів творчості педагогічної персоналії. Це потребує критичного ставлення біографа до неї як продуцента джерела особового походження, що використовується для реконструкції тї ж біографії. Отже, ці підходи акцентують на тому, що в джерелах особового походження інформація має особистісно-персоналізований характер, бо одночасно є продуктом свідомості персоналії та документальним матеріалом для вивчення іiі життевого шляху.

Означений науковий здобуток орієнтує на врахування при вивченні педагогічних персоналій трьох важливих особливостей джерел особового походження: ретроспективність, документальність, суб'єктивність. Вони настільки взаємопов'язані і переплетені між собою, що потребують розгляду в одному контексті.

Ці особливості вказують на зверненість джерел особового походження у минуле, хоча іï часові рівні (проміжки) різні, коливаються від майже синхронних у щоденниках, листуванні до можливо доволі значних в автобіографіях, спога- дах, що накладає свій відбиток на зміст (факти, оцінки, характеристики) й інтерпретацію інформації. Чим більшою $є$ часова відстань між подіями і часом написання мемуарів, тим активніше автор залучає додаткові документи, які інтерпретує з позицій їхнього сучасника і безпосереднього або опосередкованого учасника та через призму власних переживань, мотивів і завдань, що спонукали «взятися за перо». Суб'єктивність мемуаристики розглядаємо не як недолік, а ії невід'ємну властивість, адже закладена в ній інформація апріорі має мати особистий відбиток, бо в іншому випадку вона як жанр втрачає сенс. Це зумовлено особистісним ставленням автора до описуваних подій, його світоглядними уподобаннями, характером соціальних відносин, емоційним складом характеру, що, однак, не може виправдовувати відвертої тенденційності, свідомої фальсифікації.

Отже, в особових фондах державних архівів і бібліотек України нагромаджено величезний обсяг різновидових документів про широко і мало відомих педагогів. Лише незначна їхня кількість опрацьована і введена до обігу історикопедагогічної науки. А решта (абсолютна більшість таких матеріалів) чекає на свого сумлінного, прискіпливого дослідника, який має бути грунтовно обізнаним з історіографічним доробком української історико-педагогічної біографістики та володіти загальною ерудицією і культурою джерелознавчого аналізу.

\section{СПИСОК ВИКОРИСТАНИХ ДЖЕРЕЛ}

1. Гудим В. В. Фонди особового походження державного архіву Полтавської області джерело $з$ історії краю / В.В.Гудим // Архіви України. - 2013. - № 7. - С. 94-104.

2. Колобов О.О. Значення фондів особового походження для історико-біографічних досліджень. Українська біографістика / О. О. Колобов. - 1999. - № 2. - С. 201-212.

3. Особисті архівні фонди відділу рукописів. Анотований покажчик / кол. Є. М. Гуменюк та ін. ; відл. ред. Є. М. Стасюк. - Львів : АН УРСР, Львівська наукова бібліотека ім. В. Стефаника, 1977. - 181 с.

4. Особові архівні фонди Інституту рукопису: путівник / Національна академія наук України ; Національна бібліотека України ім. В. І. Вернадського, Інститут рукопису. - К., 2002. -768 c.

5. Сінкевич Ю. Документи особового походження у фондах державного архіву Херсонської області : зб. наук. допов. архів. читань (Херсон, 19 квітня 2012 року). Херсон : Айлант, 2012. - С. 18-23.

6. Центральний державний історичний архів України, м. Львів. Путівник / авт. упоряд О. Гнєвишева та ін. - Львів - К., 2001. - 387 с. 
12

\section{REFERENCES TRANSLATED}

AND TRANSLITERATED

1. Hudym V. V. Fondy osobovoho pokhodzhennia derzhavnoho arkhivu Poltavs'koi oblasti dzherelo $\mathrm{z}$ istorii kraiu / V. V. Hudym // Arkhivy Ukrainy. - 2013. - №7. - S. 94-104.

2. Kolobov O. O. Znachennia fondiv osobovoho pokhodzhennia dlia istoryko-biohrafichnykh doslidzhen'. Ukrains'ka biohrafistyka / O. O. Kolobov. - 1999. - № 2. - S. 201-212.

3. Osobysti arkhivni fondy viddilu rukopysiv. Anotovanyi pokazhchyk / kol. Ye. M. Humeniuk ta in. ; vidl. red. Ye. M. Stasiuk. - L'viv : AN URSR, L'vivs'ka naukova biblioteka im. V. Stefanyka, 1977. - 181 s.

4. Osobovi arkhivni fondy Instytutu rukopysu:
Putivnyk / Natsional'na akademiia nauk Ukrainy ; Natsionalna biblioteka Ukrainy im. V. I. Vernads'koho, Instytut rukopysu. - K., 2002. - 768 s.

5. Sinkevych Yu. Dokumenty osobovoho pokhodzhennia $\mathrm{u}$ fondakh derzhavnoho arkhivu Khersons'koi oblasti : zb. nauk. dopov. arkhiv. chytan' (Kherson, 19 kvitnia 2012 roku). Kherson : Ailant, 2012. - S. 18-23.

6. Tsentral'nyi derzhavnyi istorychnyi arkhiv Ukrainy, m. L'viv. Putivnyk / avt. uporiad O. Hnievysheva ta in. - L'viv - K., 2001. - 387 s. 